\title{
Influence of dietary lipid sources on carcass traits of broilers
}

\author{
F.H. de Witt ${ }^{1 \#}$, S.P. Els ${ }^{1}$, A. Hugo ${ }^{2}$, H.J. van der Merwe ${ }^{1}$ and M.D. Fair ${ }^{1}$ \\ ${ }^{1}$ Department of Animal, Wildlife and Grassland Science, \\ ${ }^{2}$ Department of Microbial, Biochemical and Food Biotechnology \\ P.O. Box 399, University of the Free State, Bloemfontein 9300, South Africa
}

\begin{abstract}
A study was conducted to determine the influence of different dietary lipid sources on dressing percentage, breast meat yield and breast weight of male broiler birds. Four isoenergetic (15.1 MJ AME/kg $\mathrm{DM}$ ) and isonitrogenous (222.3 g CP/ $\mathrm{kg} \mathrm{DM}$ ) diets were formulated, using high oleic sunflower oil (HO), sunflower oil (SO), fish oil (FO) and tallow (T) at a $60 \mathrm{~g} / \mathrm{kg}$ dietary inclusion level. Four hundred, day-old Ross 788 broiler males were randomly allocated to the four treatments $(n=100)$ and further subdivided into four replicates/treatment $(n=25)$. All birds receive a standard commercial diet for the first 14 days, whereafter the experimental diets were fed for another 28 days. At 42 days of age, three birds/replicate $(\mathrm{n}=$ $12 /$ treatment) were randomly selected, weighed and slaughtered at a commercial abattoir. Chilled carcasses $\left(4{ }^{\circ} \mathrm{C}\right)$ were weighed to determine dressing percentage. Breast muscles were removed from the chilled carcasses, skinned and weighed for the calculation of breast meat yield. Breast meat yield were expressed as a percentage of the live body weight as well as carcass weight. This study showed that the broilers fed a diet supplemented with $60 \mathrm{~g} / \mathrm{kg}$ tallow had a better dressing percentage, breast meat yield and breast weight compared to other treatments. These results suggested that dietary lipid sources could be used to improve certain carcass traits of broilers.
\end{abstract}

Keywords: Ross 788, fatty acids, dressing percentage, breast meat yield

\#Corresponding author. E-mail: dewittfh.sci@ufs.ac.za

\section{Introduction}

Cardiovascular diseases in mankind are mostly ascribed to either a family history of these problems and/or of dietary origin. Modern diets high in saturated fatty acids (SFA) and low in monounsaturated (MUFA) and polyunsaturated (PUFA) fatty acids are mostly blamed for the increased incidence of these diseases. Since dietary fatty acids are absorbed by monogastric animals and deposited in their tissues without significant modification (Coetzee \& Hoffman, 2002) considerable potential exists for the manipulation of the fatty acid profile of poultry meat and eggs. The manipulation of poultry protein sources has the potential to increase the supply of omega-3 (n-3) PUFA's as well as to improve the PUFA/SFA ratio (Warnants et al., 1998) and the n-6/n-3 ratios (Wood et al., 1999) in human diets. Accordingly, Coetzee \& Hoffman (2002) was able to reduce the n-6/n-3 ratio in broiler meat and adipose tissue to a more suitable level of 5:1 for human consumption, thereby, illustrating the potential of dietary manipulation in the production of "healthier" chicken meat according to consumer demand.

The use of dietary fatty acids to manipulate the fatty acid profile is, however, controversial in terms of production related aspects. It seems as if flaxseed oil and fish oil have generally no adverse effects on production performances (Olomu \& Baracos, 1991; López-Ferrer et al., 1999) but the use of flaxseed or flaxseed meal may cause diarrhoea and adverse growth performances (González-Esquerra \& Leeson, 2000). It also seems that the uneven distribution of $n-3$ fatty acid in the different marketable meat portions complicate the enrichment and marketing of these products (González-Esquerra \& Leeson, 2001). Rebolé et al. (2006) recorded a significant linear relationship between C16:0 and C18:1n-9 in white meat $\left(\mathrm{r}^{2}=0.88\right)$ and dark meat $\left(\mathrm{r}^{2}=0.90\right)$, suggesting that specific body tissues could be manipulated more efficiently according to the dietary fatty acid profile.

Since new genetic broiler lines are also selected according to specific carcass traits such as breast meat yield and dressing percentage, the importance of dietary manipulation on these parameters becomes important. However, literature regarding the effects of dietary lipid sources on breast meat yield is scarce and 
inconsistent, especially at high inclusion levels $(60 \mathrm{~g} / \mathrm{kg})$ where the production efficiency of birds is improved, and needs further verification.

The aim of the study was to determine the influence of different dietary lipid sources on dressing percentage, breast weights and breast meat yield of male broiler chickens.

\section{Materials and Methods}

All procedures conducted during this study were approved by the Control Committee for Animal Experimentation of the University of the Free State (Animal Experiment No. 11/07). Four hundred, day-old Ross 788 broiler males were obtained from a commercial hatchery and randomly allocated to the four dietary treatments $(n=100 /$ treatment $)$. Each treatment was further subdivided into four replicates (25 birds/replicate). Birds received a commercial starter diet for the first 14 days, where-after the experimental diets were fed for 28 days until termination of the study. Four experimental diets (mash form), with a calculated isoenergetic (15.1 MJ AME $/ \mathrm{kg} \mathrm{DM})$ and isonitrogenous $(222.3 \mathrm{~g} \mathrm{CP} / \mathrm{kg} \mathrm{DM})$ content were formulated by using high oleic sunflower oil (HO), sunflower oil (SO), fish oil (FO) and tallow (T) at a 60.0 $\mathrm{g} / \mathrm{kg}$ dietary inclusion level. The calculated chemical composition of the experimental diets is indicated in Table 1.

Table 1 The calculated chemical composition $(\mathrm{g} / \mathrm{kg} \mathrm{DM})$ of the experimental diets with a $60 \mathrm{~g} / \mathrm{kg}$ lipid inclusion

\begin{tabular}{cc}
\hline & $\mathrm{g} / \mathrm{kg} \mathrm{DM}$ \\
\hline Protein & 222.3 \\
$\mathrm{AME}^{1}(\mathrm{MJ} / \mathrm{kg} \mathrm{DM})$ & 15.1 \\
Fat & 99.5 \\
Ash & 66.1 \\
Neutral detergent fibre & 94.3 \\
Acid detergent fibre & 51.8 \\
Calcium & 10.1 \\
Phosphorus & 7.6 \\
Chlorine & 1.2 \\
Sodium & 1.9 \\
Potassium & 8.6 \\
Magnesium & 2.3 \\
Arginine & 14.8 \\
Isoleucine & 9.3 \\
Lysine & 13.3 \\
Methionine & 6.1 \\
Threonine & 8.3 \\
Tryptophan & 2.7 \\
Methionine \& Cystine & 10.1
\end{tabular}

${ }^{1}$ Apparent metabolizable energy (MJ/kg DM).

Birds were reared inside a natural ventilated building on cement floor $\left(12 \mathrm{birds} / \mathrm{m}^{2}\right)$ using sawdust as bedding. Feed and water provision was on an ad libitum basis and an $18 \mathrm{~h}$ photoperiod was allowed throughout the experimental period. At 42 days of age, three birds/replicate $(n=12 /$ treatment) were randomly selected, weighed, marked and slaughtered at a commercial abattoir. Carcasses were stored at $4{ }^{\circ} \mathrm{C}$ $(24 \mathrm{~h})$ before determining cold carcass weight and dressing percentage. Breast muscles were removed from the chilled carcasses, skinned and weighed for the calculation of breast meat yield. Breast meat yield was expressed as a percentage of live body weight (BBW). The PROC ANOVA procedures of the SAS programme (SAS, 1999) were used to test for significant $(\mathrm{P}<0.05)$ differences between dietary treatments while Tukey's studentized range (HSD) test was used to identify these differences. 


\section{Results and Discussion}

The effects of different dietary lipid sources on dressing percentage, breast weight and BBW of male broiler chickens are indicated in Table 2. The tallow (SFA) treatment resulted in the highest dressing percentage, breast weight and BBW. No differences $(\mathrm{P}>0.05)$ were recorded on any of the tested parameters between tallow and high oleic sunflower oil (MUFA) treatments. From the results of the present study, it seems that an increase in polyunsaturated fatty acids (sunflower- and fish oil) of the dietary lipid sources would result in a lower dressing percentage, breast weight and BBW. Contrary to the present findings, Crespo \& Esteve-Garcia (2001) reported that neither dietary lipid source nor inclusion level (60 and 100 $\mathrm{g} / \mathrm{kg}$ ) had an effect $(\mathrm{P}>0.05)$ on dressing percentage, thigh- and breast weights of Ross 208 males and females. These differences in results between the present and former study could probably be ascribed to genetic differences between breeds and their respective allometric growth ratios of breast muscle.

Table 2 The effect of different dietary lipid sources at a $60 \mathrm{~g} / \mathrm{kg}$ inclusion level on carcass traits of broiler males (Mean \pm s.e.)

\begin{tabular}{cccc}
\hline Lipid source & Dressing $\%$ & Breast weight $(\mathrm{g})$ & BBW $^{1}(\%)$ \\
\hline High oleic sunflower oil & $69.8^{\mathrm{ab}} \pm 0.5$ & $503.0^{\mathrm{ab}} \pm 18.4$ & $17.4^{\mathrm{ab}} \pm 0.4$ \\
Sunflower oil & $69.7^{\mathrm{b}} \pm 0.3$ & $488.3^{\mathrm{b}} \pm 12.8$ & $17.1^{\mathrm{ab}} \pm 0.3$ \\
Fish oil & $68.9^{\mathrm{b}} \pm 0.3$ & $495.7^{\mathrm{ab}} \pm 13.0$ & $17.0^{\mathrm{b}} \pm 0.2$ \\
Tallow & $71.2^{\mathrm{a}} \pm 0.4$ & $564.7^{\mathrm{a}} \pm 46.9$ & $18.5^{\mathrm{a}} \pm 0.4$ \\
P & 0.0020 & 0.0245 & 0.0304 \\
$\mathrm{CV}^{2}(\%)$ & 1.3 & 10.1 & 6.1
\end{tabular}

\footnotetext{
${ }^{\mathrm{a}, \mathrm{b}}$ Parameter means \pm s.e. with different superscripts within columns differ significantly $(\mathrm{P}<0.05)$.

1 BBW - Breast meat yield a \% of live body weight.

${ }^{2}$ Coefficient of variation $(\%)$.
}

Crespo \& Esteve-Garcia (2001) and Özdoğan \& Akşit (2003) found that different dietary fats had a significant effect on the ash content of thigh- $(\mathrm{P}<0.05)$ and breast muscle $(\mathrm{P}<0.01)$. Özdoğan \& Akşit (2003) reported that dietary tallow (SFA) resulted in the highest ash content (1.10\%) of both muscles, while sunflower oil (PUFA) resulted in the lowest ash content $(0.98 \%)$. These results of the former authors could probably explain why tallow resulted in the highest while sunflower oil resulted in the lowest breast weight during the present study (Table 2).

Rebolé et al. (2006) found a highly significant $(\mathrm{P}<0.001)$ linear relationship $\left(\mathrm{r}^{2}=0.88\right)$ between palmitic acid (C16:0) and oleic acid (C18:1, n-9) in white- (breast) as well as brown (thigh) muscle and they reported that the coefficient of determination between MUFA and SFA $\left(\mathrm{r}^{2}=0.92\right)$ was also very high in these meat samples. Since tallow (SFA) and high oleic sunflower oil (MUFA) have high levels of palmiticand oleic acid respectively, the non-significant $(\mathrm{P}>0.05)$ differences between these two dietary treatments (Table 2) could be ascribed to their linear relationship as recorded by Rebolé et al. (2006).

Vilà \& Esteve-Garcia (1996), Zollitsch et al. (1997) and Crespo \& Esteve-Garcia (2001) reported that an increased fat content of the diets, especially SFA (tallow and lard), produced higher abdominal fat deposits in birds since energy originating from SFA's are easier deposited in the fat pad and/or around the internal organs, than that from UFA's which is metabolically used. Crespo \& Esteve-Garcia (2001) suggested that energy retention increase with the feeding of SFA, while energy expenditure should increase when PUFA are fed to birds, independently of the changes in lipid synthesis. It is therefore possible that the feeding of PUFA, resulted in a higher oxidation of dietary fatty acids. More oxidation of dietary PUFA could lead to more synthesis of endogenous fatty acids from carbohydrates, with a consequent higher energy cost than if they were directly deposited from the diet itself (Emmans, 1994). These differences in efficiency of energy utilization between SFA's and PUFA's could be liable for differences observed in the yield of breast muscle during the present study. Another incalculable factor that requires further research is the effect of different fatty acids (SFA, MUFA and PUFA) on hormonal production and the composition of hormones. Shirai et al. (2004) reported that the dietary intake of polyunsaturated fatty acids is negatively correlated with 
plasma leptin concentration. In another report, Pérez et al. (1997) illustrate that cis-unsaturated free fatty acids such as oleic acid are able to inhibit the secretion of growth hormone (GH) and prolactin (PRL) secretion. Consequently, a change in GH and leptin concentrations will result in alterations of the muscle: adipose tissue deposition. However, it seems that the influence of dietary fatty acids on hormonal secretion and its subsequent effect on body composition is still a vague concept that warrants further investigation.

\section{Conclusions}

Results of the present study indicated that different dietary fatty acids have an influence on the dressing percentage as well as carcass traits of broiler males. The results shown that the dietary inclusion of saturated fatty acids (tallow) resulted in the highest dressing percentage, breast weight and breast meat yield. These results suggested that high dietary inclusion levels $(\geq 60 \mathrm{~g} / \mathrm{kg})$ of unsaturated fatty acids to improve energy density of diets and/or to manipulate the fatty acid composition of birds could have a detrimental effect on certain carcass traits.

\section{References}

Coetzee, G.J.M. \& Hoffman, L.C., 2002. Effects of various dietary n-3/n-6 fatty acid ratios on the performance and body composition of broilers. S. Afr. J. Anim. Sci. 32, 175-184.

Crespo, N. \& Esteve-Garcia, E., 2001. Dietary fatty acid profile modifies abdominal fat deposition in broiler chickens. Poult. Sci. 80, 71-78.

Emmans, G.C., 1994. Effective energy: a concept of energy utilization applied across species. Br. J. Nutr. 71, 801-821.

González-Esquerra, R. \& Leeson, S., 2000. Studies on the metabolizable energy content of ground full-fat flaxseed fed in mash, pellet and crumbled diets assayed with birds of different ages. Poult. Sci. 79, 1603-1607

González-Esquerra, R. \& Leeson, S., 2001. Alternatives for enrichment of eggs and chicken meat with omega-3 fatty acids. Can. J. Anim. Sci. 81, 295-305.

Lopez-Ferrer, S., Baucells, M.D., Barroeta, A.C. \& Grashorn, M.A., 1999. N-3 enrichment of chicken meat using fish oil: Alternative substitution with rapeseed and linseed oils. Poult. Sci. 78, 356-365.

Olomu, J.M. \& Baracos, V.E., 1991. Influence of dietary flaxseed oil on the performance, muscle protein deposits and fatty acid composition of broiler chicks. Poult. Sci. 70, 1403-1411.

Özdoğan, M. \& Akşit, M., 2003. Effects of feeds containing different fats on carcass and blood parameters of broilers. J. Appl. Poult. Res. 12, 251-256.

Pérez, F.R., Casabiell, X., Camiña, J.P., Zugaza, J.L. \& Casanueva, F.F., 1997. Cis-unsaturated free fatty acids block growth hormone and prolactin secretion in thyrotrophin releasing hormone stimulated $\mathrm{GH}_{3}$ cells by perturbing the function of plasma membrane integral proteins. Endocrinology 138, 264-272.

Rebolé, A., Rodríguez, M.L., Ortiz, L.T., Alzueta, C., Centeno, C., Viveros, A, Brenes, A. \& Arija, I., 2006. Effect of dietary high-oleic acid sunflower seed, palm oil and vitamin E supplementation on broiler performance, fatty acid composition and oxidation susceptibility of meat. Br. Poult. Sci. 47, 581-591.

SAS, 1999. SAS ${ }^{\circledR}$ User's Guide. Version 6.12. SAS Institute Inc. Cary, N.C., USA.

Shirai, Y., Yaku, S. \& Suzuki, M., 2004. Metabolic regulation of leptin production in adipocytes: a role of fatty acid synthesis intermediates. J. Nutr. Biochem. 14, 651-656.

Vilà, B. \& Esteve-Garcia, E., 1996. Studies on acid oils and fatty acids for chickens. I. Influence of age, rate of inclusion and degree of saturation on fat digestibility and metabolisable energy of acid oils. Br. Poult. Sci. 37, 105-117.

Warnants, N., Van Oeckel, M.J. \& Boucqué, C.H.V., 1998. Effect of incorporation of dietary polyunsaturated fatty acids in pork backfat on the quality of salami. Meat Sci. 49, 435-445.

Wood, J.D., Sheard, P.R., Enser, M., Nute, G.R., Richardson, R.I. \& Gill, B.P., 1999. Increasing the n-3 polyunsaturated fatty acid content of pig meat and effects on meat quality. Proc. $45^{\text {th }}$ Int. Congr. Meat Sci. Technol., p. 672-673. Yokohama, Japan.

Zollitsch, W., Knaus, W., Aichinger, F. \& Lettner, F., 1997. Effects of different dietary fat sources on performance and carcass characteristics of broilers. Anim. Food. Sci. Technol. 66, 63-73. 